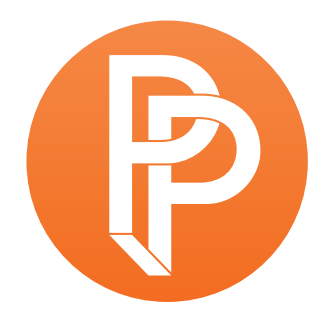

PERFORMANCE

PHILOSOPHY

\title{
EXCEPTIONALISM, SCHIZOPHRENIA, ARTAUD: ON JUDGMENT
}

KÉLINA GOTMAN KING'S COLLEGE LONDON

At the heart of this paper sits (or quivers) a paradox, an irritation: Artaud suffuses contemporary theatre and philosophy. Yet Artaud, like Deleuze, arguably begs not to be written. Artaud's work resists hermeneutic closure, just as Deleuze and Guattari's pliable, plastic concepts at the outset attempt to resist rigidification: the 'body without organs', a term of Artaud's that Deleuze and Guattari recuperated and transformed, once utilized as a fixed concept, loses the resistance to judgment and to individuation it set out to describe. I have attempted to write about Artaud for a number of years. I have always hit a wall as I do so. This paper attempts to untangle this impasse, to think through the violence of passage 'over to' Artaud, imagined in modern philosophy and performance as an island far outside of yet uncannily within all of 'us': primal and essential, incontournable, at once. This paper attempts, like Deleuze, to make philosophy "in the backs" of others (Deleuze [1990] 2003, 15), to resist speaking at or about but instead insolently beside or through others, to try to get at something else.

This impulse is arguably contrary to the impulse of 'criticism', which seeks to explain, to name, and to theorize. In theorizing, we do what Henri Bergson (1938) suggested concepts always attempt to do: fix, like a photographic still, a world that is otherwise more fluid, more dynamic than they are. One can counter to this notion another notion, that concepts too are fluid; that they transform. This is what Deleuze and Guattari did in Qu'est-ce que la philosophie? [What Is Philosophy?] (1991), their last work together, in which they attempt to think through the task of philosophy itself. Philosophy, they argue, makes concepts: it fashions them; but these concepts are pliable. They have histories that zigzag; that encounter other histories and overlap with them. Also, one might 
add, histories that affect other histories: concepts are always in motion. And these concepts 'change' the 'reality' of the room: they do not just represent, but take part in the world they appear, according to Bergson, to describe.

Why even try to write about Artaud? The discourse surrounding Artaud's 'exceptionalism' gets, once again, to the heart (the gut, perhaps) of modern and contemporary philosophy and performance's joint investments in the problem of criticism as a problem of judgment. Ever since Kant, if not before, the philosophical problem par excellence has been judgment. According to Deleuze (1993), in an essay on Artaud, Nietzsche, D. H. Lawrence, and Kafka, judgment binds modern philosophy and drama, specifically tragedy; and it has done so since the Greeks. In tragedy, judgment is the action around which all others lie: in Antigone, judgment of the individual against a social order she refuses; in Agamemnon, judgment of a father who chose power over kinship. After Kant, philosophers judge what is beautiful, good; what is ethical. They describe and judge. A philosopher who does not judge, consequently is not a philosopher: this has been the accusation leveraged against a long line of Continental thinkers who chose plasticity, pliability, escape over categorical decisions, the stark contrast of a yes or a no. After WWII and the student upheavals of May 1968 in Paris, hierarchies putatively dissolved or were shaken; motion came to be a principle of historical agency almost on its own terms, differently from what Marx had conceived. No longer were philosophers bringing change to the world; their whole relationship to the world was in question. They did not just reflect on a world exterior to them; they were part of a world, literally in the streets, for some. Between subject and object, a chasm fell. Philosophy had to change too. It became, in this sense, performative. It began to act.

But with this acting, came further accusations of fakery, charlatanism. These philosophers only spun words, the dissolution between subject and object, thinking mind and hard thing did not meet in a moving, fluid, vital world of cross-pollination, mutually invested flows, but stopped, apparently, at a page on which subjects and objects became confused, indistinguishable. This was largely leveraged against Derrida, the writer-poet par excellence, whose attempts at decentering a center, remarginalizing a heavy body of philosophical thought met with equal critique, largely from the other side of the Channel, in debates so memorialized they hardly bear repeating here. Like Deleuze, Derrida met Artaud in a playful, performative space of philosophical recuperation: Artaud invited thinking, his work and person invited different ways of thinking, a zone between "criticism" and the "clinic" ("critique" and "clinique," as Derrida writes in "La parole soufflée" [1967]). Psychiatry was in a shambles, in the wake of experiments by R. D. Laing, Félix Guattari and others: not only in the pages of Foucault's writing, after Georges Canguilhem, but in practice, hierarchies and concepts of normalcy were being radically rewritten. A 'mad' person, an 'aliéné mental' may not be mad; according to the tenets of schizo-analysis, the world around them was madder. They became mad because they 'failed' (arguably, in one way or another, refused) to 'fit' within a society whose bureaucracies, and petty methods of social control, stifled them. In order to be 'cured' they only needed to find alternative ways of being in this world, not like Kafka crushed by the weight of futility, but by picking up a paintbrush, say (in the case of Mary Barnes, at the famous antipsychiatric Kingsley Hall [Guattari 1995]). Society had judged them; but taken from a different perspective, it was the society, the whole edifice of society, that was sick. 
Critic and clinic jointly floundered, and with them tragedy and philosophy came tumbling down too. In their place, rose performance. And at the crest of this wave, rode the spectre of Artaud. His madness, from a schizoanalytical perspective, was not madness; as he wrote of Van Gogh, in Van Gogh, suicidé de la société (1947), the society around them was perverse. In the case of Van Gogh, it cannibalized a man whose pores were open, too open, like the skies at night that he painted. Society had seeped in through his pores to destroy him. Writing in Pour en finir avec le jugement de dieu (1947), his final radio play, a recording initially commissioned for public broadcast in February 1948 but subsequently banned by Radio France, and the only true expression of the theatre of cruelty, in his terms, Artaud tried to do away with this sick society. To exorcise it. In his contemporary rendition of Artaud's play, Kentish composer Adam de la Cour rewrites Artaud's xylophonie, his cries, his screams with a graphic score reprising some of Artaud's drawings; clarinettist Carl Rosman toggles between a bass clarinet, drum, and vocalization uncannily like Artaud's own, while pianist Mark Knoop performs a continuous surge of highly contrasting, frequently tumultuous, Bach-infused noise, texture, notes. This work, L'Exorcisme du Mômo (2008), what de la Cour calls "an exorcism in four parts," arguably sits entirely outside or beside judgment. ${ }^{1}$ It also seeks to exorcise Artaud - who called himself a "mômo," slang for "madman," in derision against those who judged him as such, and in self-mockery - to purge him from a world of overtheorization, offer a work with, rather than at him, without regard to what it might mean to be delirious, schizophrenic, insane, all terms Artaud had suffered during his near decade of psychiatric institutionalization, beginning in 1938 at the Sainte Anne hospital, where he was admitted after an explosive trip to Ireland. He had gone as Saint Patrick, equipped with St. Patrick's walking stick, in search of the saint's birthplace. Dr. Jacques Lacan, who saw Artaud at Sainte Anne, described him as "incurable." And for nine years, until his release from the Rodez hospital in southern France, Artaud was institutionalized, also malnourished, and supported from time to time, by Dr. Gaston Ferdière in particular, in his endeavours to draw and to write (Artaud [1947] 2003, 183).

Pour en finir avec le jugement de dieu was commissioned by Fernand Pouey for a new programme, "La voix des poètes » (Poets' voices or, more accurately, the poets' voice, in fact suggesting the singularity of a voice in spite of a plurality of poet bodies). Artaud spent months writing and subsequently recording his text, with his friends and collaborators Paule Thévenin, Roger Blin and Maria Casarès. But Wladimir Porché, director general at Radio France, vetoed the broadcast once he had heard the result. ${ }^{2}$ A surge of protestation and public debate ensued, a veritable "Affaire Artaud," with articles in dozens of French newspapers on the Left and the Right pouring over the purported pros and cons of this decision (Artaud [1947] 2003, 190-210). Artaud came to be at the center of a national drama about judgment: about whether it was right or wrong to judge a work made by a man who was putatively exceptional, who exceeded the boundaries of good taste and bienséance, or normally acceptable behaviour. His recording became a "human document," in the words of some, who defended its broadcast on the grounds that he was an exception. ${ }^{3}$ Many supporters claimed that he was a poète maudit, like Baudelaire and Rimbaud before him; the society itself would be judged by future generations, if like Baudelaire and Rimbaud's contemporaries, it was too short-sighted to recognize a genius walking in its midst. In all this, Artaud dissolved. In fact, he himself experienced a reversal of his own conception of his self and place within or without this society. Whereas Pour en finir avec le jugement de dieu called for a 
revolution among the peasant and worker classes, whom he called upon to rise up against a corrupt new world order governed by the Americans and Russians racing to war and militarization, as well as hyper-technologization, expecting this audience of normal people to greet his work with open arms, he discovered after a second private broadcasting of his work that this audience was not yet ready. Crestfallen, he wrote in a letter to Thévenin that he had suddenly understood that his work was not yet ready to be received; his true audience was not yet born (Artaud [1947] 2003, 104-5).

This pushed his theatre of cruelty onto a future plane, and so too, as has been emphasized again and again by criticism in its wake, onto a plane of supposed impossibility. Artaud's theatre is putatively theoretical, this view suggests, not only because he wrote few play texts (though Kimberly Jannarone [2010] has been at great pains to show not only that his politics were less leftleaning than some commentators allow, but also that his theatre work as a director has been radically overlooked). But because his writing - his "manifesto" for a theatre of cruelty - was philosophical: it judged the world around it as corrupt, and proposed a vision for how this world could be excised, replaced, improved upon.

Yet what these readings often fail to address is the extent to which Artaud sought real action in the world through his public broadcasting, a commission that had promised him an audience of 15 million listeners. As a performance, it meant not only to reflect on, but to change the world, and it was actual; the recording he intended for this effect did take place. It was heard by a small socalled "circle of initiates," specially called on to help determine whether it would be fit for public consumption; and on the initiative of a new student press, Nyza, followed by the independent $\mathrm{K}$ éditeurs, it found a life on the page, though he had said publication of the text without attendant sounds would be a "disaster" (Artaud [1947] 2003, 98-99).

What I aim to suggest is that with Pour en finir avec le jugement de dieu, Artaud eschews modern philosophy and tragedy, inasmuch as he eschews the institution of judgment: that which, he says, he suffered from his entire life. He does this by undercutting the very concept of individuality: that against which, as Deleuze reminds us in "Pour en finir avec le jugement," judgment necessarily strikes. Without organs organising a body into an individual person, and without a legal, social, political and philosophical system conceptualising of this organised body as an individual entity that can take action and suffer the consequences of these actions against a supposedly coherent social whole, the "self" dissolves into pure porosity. But also, as Artaud suggests in his radio play, it dissolves into the mountains, the earth. It offers an ecological, or what Guattari has called an ecosophical conception of human life integrated with other elements: death, stars, etc. In this view, as in schizoanalysis, human life is not separated from the sphere of action within which it purportedly operates and against which it might be judged. Without individuation, there is no judgment, and so too, no injustice: there can be no injustice against individual beings, since there are no beings who are individuated (and can be singled out). This phantasmagorical vision does not on that account resist intensities. On the contrary, beings are intensities, who can exercise violent, powerful forces through the world, but who don't suffer the weight of gravity according to which there is only one way to move: forward, and down. In the dance of the Tutuguri Indians of 
Mexico, from whom Artaud sought inspiration after his visit there in 1936, people are free to dance backwards, inside out ("danser à l'envers"), back to front, front to back and, above all, back to back ("d'arrière en avant et/ d'avant en arrière/ mais beaucoup plus d'arrière en arrière") (Artaud [1947] 2003, 33-35; see also Artaud 1971a; Artaud 1971b). This radically decenters the world of dance and theatre and concepts of individuality on which modern philosophy and tragedy are based.

At the same time, Artaud was violently disindividualized, in a different sense: a vulturous, yet paradoxically adulating projection of his person onto an abstract plane that said he represented exceptionalism as such, the exceptionalism of poet outcasts, martyrs of a society that wanted to see itself as progressive, enlightened, but was afraid of the retrospective judgment, the mockery, of French society - and potentially of the world's - hindsight. If Artaud was to have been considered a genius, these men and women who had chastised him would look like fools.

In Omar Shahryar, Joanna Young, Sarah Eldin and Felipe Otondo's To have done with the judgment of Artaud, performed at the Edinburgh Fringe festival in 2007 (Base Theatre 2007), Artaud once again appears as a spectral individual it is impossible to reckon with except by recorporealizing his cries, juxtaposing these to recordings he himself made, and which are now publicly available (Artaud 1947; Artaud [1947] 1995; Artaud [1947] 1996). The entanglement of representation, recorporealization, and repetition, reverberation or echo uncannily pay homage to Artaud's work and refuse the homage, transforming his work in the process. Their piece offers a version of his work that by its title already refuses the hyperindividualization and what I would venture to call the discourse of utter alterity that has surrounded him, subjecting Artaud to a public theatre of support purporting an enlightened refusal of judgment that paradoxically judges him on the same. In this view, he is so exceptional he is not even allowed to attend his own public trial.

This making-tragedy of his life and work has rendered it aporetic, impossible, and at the same time hypertrophic: Artaud becomes the tragic hero, in a drama of reindividuation whose only outcome seems to be an infinitely receding philosophical discourse predicated on his utter alterity: an utter alterity he refused, as he sought to remain both like everyone else and multiple. In an article on the use of the "schizophrenic" in contemporary theory, Catherine Prendergast (2008) takes Deleuze and Guattari, Baudrillard, Jameson, and others to task for relying on the figure of the "exceptional" schizophrenic as representative of all that is non-normative, anti-capitalistic, creative, disinhibited, free, and ultimately more closely connected to reality than everyone else. She argues that a far greater number of "unexceptional" than "exceptional" schizophrenics populate the halls of hospitals, schools and factories in everyday life, and that they are not helped by the grossly distorted, romantic terms postmodern and poststructuralist theory have imposed. These "unexceptional" schizophrenics, she points out, are concerned with job retention, benefits, medical care, and the not insignificant challenge of having their own "voice." Paradoxically, Artaud too, the quintessential, arguably the paradigmatic "exceptional" schizophrenic in modern and contemporary thought, suffered from this same discourse of exceptionalism, which extracted him from the simple, stupid pleasures of human concourse and horizontal affiliation. 
In attempting to dramatize the violence of judgment and of the institutions that box and quarter people who fail to fit these bounds - all of whom suffer in one way or another from this disconnection - Artaud made a work in which he attempted performatively to extract himself from the individualizing impulse of philosophy, a stand-in for the God who judges, while maintaining in everyday life to be an individual capable of political agency. That he has only come to be all the more adulated in philosophy and attendant fields suggests that the performance of selfimmolation, negativity and refusal, only excites critique further. Criticism and clinicalism are still not so far apart. Even poststructuralist philosophy, which performs flow, and attempts to thinkwith, teeters at the edge of hypertrophism.

This is why I did not want to write on Artaud, and yet why, at the outset of a venture that purports explosively to commingle philosophy and drama, in a performative orgasm of holy communion, it seems urgent to attempt to reckon again with what may be construed as an originary act, a moment of drama and philosophy that is arguably also neither.

Notes

\begin{abstract}
${ }^{1}$ L'exorcisme du Mômo was premiered at the Schott recital room (De la Cour 2010), and performed again at Clapham Omnibus, part of the Infancy, History \& the Avant-Garde festival (2015) curated by Steve Potter and myself.

${ }^{2}$ Detailed notes regarding the scandal surrounding Artaud's commission by Fernand Pouey and its subsequent ban by Porché, as well as excerpts from the press and attendant documents, appear in Artaud ([1947] 2003), 190228. Artaud's letters are reproduced in Artaud ([1947] 2003), 83-105. See also esp. Artaud (1974).

${ }^{3}$ The term appears simultaneously on 7 February 1948 in an article by Max Favalelli in Paris-Presse, cited in Artaud ([1947] 2003), 203, and by the journalist René Guilly in the leftist Combat; Guilly calls Artaud's work an "exceptional human document" ["un document humain exceptionnel"] (Artaud [1947] 2003, 218). Pierre Laroche wrote on 11 February in the satirical Le Canard enchainné that the radio broadcast was "a surprising human - even superhuman - document" ["un étonnant document humain et même surhumain"] (Artaud [1947] 2003, 205).
\end{abstract}

\title{
Works Cited
}

Artaud, Antonin. 1947. Pour en finir avec le jugement de dieu. Recorded November 22-29. Accessed March 18, 2015. http://www.ubu.com/sound/artaud.html.

1971a. Messages révolutionnaires. Paris: Éditions Gallimard.

1971b. Les Tarahumaras. Paris: Éditions Gallimard.

1974. Vol. 13 of Euvres complètes. Paris: Éditions Gallimard.

1995. Antonin Artaud - 2 émissions de René Farabet. Edited by Janine Antoine and René Farabet. André Dimanche Éditeur ISBN 2-86916-086-0. 4xCD+box. 
-. (1947) 1996. Pour en finir avec le jugement de dieu. Sub Rosa SR92. Compact disc.

. (1947) 2001. Van Gogh, suicidé de la société. Rev. ed. Paris: Éditions Gallimard.

. (1947) 2003. Pour en finir avec le jugement de dieu. Edited by Évelyne Grossman. Rev. and corr. ed. Paris: Éditions Gallimard.

Base Theatre. 2007. To have done with the judgment of Artaud. Created and performed by Base Theatre (Omar Shahryar, Joanna Young, Sarah Eldin and Felipe Otondo). Edinburgh, 6-11 August. Accessed March 18, 2015. http://www. otondo.net/fringe/.

Bergson, Henri. (1938) 1999. La pensée et le mouvant. Paris: Presses Universitaires de France.

De la Cour, Adam. 2010. L'exorcisme du Mômo. Recorded May 28. Accessed March 18, 2015. http://soundcloud.com/adam-de-la-cour/lexorcisme-du-m-mo.

Deleuze, Gilles. 1993. "Pour en finir avec le jugement." In Gilles Deleuze, Critique et clinique, 158-169. Paris: Les éditions de minuit.

___. (1990) 2003. Pourparlers : 1972-1990. Paris: Les éditions de minuit.

Deleuze, Gilles and Félix Guattari. 1991. Qu'est-ce que la philosophie? Paris: Les éditions de minuit.

Derrida, Jacques. 1967. "La parole soufflée." In Jacques Derrida, L'écriture et la différence, 253-292 Paris: Les éditions du Seuil.

Guattari, Félix. 1995. "Mary Barnes' Trip."' In Chaosophy, edited by Sylvère Lotringer, translated by Ruth Ohayon, 171-185. New York: Semiotext(e).

Jannarone, Kimberly. 2010. Artaud and His Doubles. Ann Arbor: University of Michigan Press.

Prendergast, Catherine. 2008. "The unexceptional schizophrenic: a post-postmodern introduction." Journal of Literary and Cultural Disability Studies 2 (1): 55-62. http://dx.doi.org/10.3828/jlcds.2.1.7.

\section{Biography}

Kélina Gotman is Lecturer in Theatre and Performance Studies in the Department of English at King's College London, and a core convenor of Performance Philosophy. She received her PhD in Theatre from Columbia University, and has taught cultural and critical theory, writing, and performance at the Eugene Lang College for Liberal Arts at the New School, Bard College and Columbia. She is translator of Félix Guattari's The Anti-Oedipus Papers (New York: Semiotext(e), 2006), and writes regularly on dance and philosophy, history and philosophy of science, performance, translation and dramaturgy. She has collaborated on well over two dozen productions in Europe and North America as an actor, director, dancer, choreographer, writer, translator, dramaturg and curator, including most recently her translation of Artaud's The Spurt of Blood [Le jet de sang (1925)] and a new work based on Georges Bataille's "Propositions" (1937) with Falmouth- and London-based electronics band Schopenhauer, both for the Infancy, History and the Avant-Garde festival she co-curated with American composer Steve Potter, the fourth in a series of projects under the aegis of their experimental opera company Recreational Services (2015). She is from Montreal.

\section{(c) 2015 Kélina Gotman}

Except where otherwise noted, this work is licensed under a Creative Commons AttributionNonCommercial-ShareAlike 4.0 International License. 